\title{
Psychological climate and individual factors as antecedents of work outcomes
}

Citation for published version (APA):

D'Amato, A., \& Zijlstra, F. R. H. (2008). Psychological climate and individual factors as antecedents of work outcomes. European Journal of Work and Organizational Psychology, 17 (1), 33-54.

https://doi.org/10.1080/13594320701307420

Document status and date:

Published: 01/01/2008

DOI:

10.1080/13594320701307420

Document Version:

Publisher's PDF, also known as Version of record

Document license:

Taverne

Please check the document version of this publication:

- A submitted manuscript is the version of the article upon submission and before peer-review. There can be important differences between the submitted version and the official published version of record.

People interested in the research are advised to contact the author for the final version of the publication, or visit the DOI to the publisher's website.

- The final author version and the galley proof are versions of the publication after peer review.

- The final published version features the final layout of the paper including the volume, issue and page numbers.

Link to publication

\footnotetext{
General rights Owners
rights.

- You may freely distribute the URL identifying the publication in the public portal. please follow below link for the End User Agreement:

www.umlib.nl/taverne-license

Take down policy

If you believe that this document breaches copyright please contact us at:

repository@maastrichtuniversity.nl

providing details and we will investigate your claim.
}

Copyright and moral rights for the publications made accessible in the public portal are retained by the authors and/or other copyright owners and it is a condition of accessing publications that users recognise and abide by the legal requirements associated with these

- Users may download and print one copy of any publication from the public portal for the purpose of private study or research.

- You may not further distribute the material or use it for any profit-making activity or commercial gain

If the publication is distributed under the terms of Article $25 \mathrm{fa}$ of the Dutch Copyright Act, indicated by the "Taverne" license above, 


\section{Psychological climate and individual factors as antecedents of work outcomes}

\section{Dr Alessia D'Amato \& Fred R. H. Zijlstra}

To cite this article: Dr Alessia D'Amato \& Fred R. H. Zijlstra (2008) Psychological climate and individual factors as antecedents of work outcomes, European Journal of Work and Organizational Psychology, 17:1, 33-54, DOI: 10.1080/13594320701307420

To link to this article: https://doi.org/10.1080/13594320701307420

曲 Published online: 22 Jan 2008.

Submit your article to this journal \lceil

Џlll Article views: 1433

Q View related articles ๘

4 Citing articles: 5 View citing articles 진 


\title{
Psychological climate and individual factors as antecedents of work outcomes
}

\author{
Alessia D'Amato \\ Center for Creative Leadership-Europe, Brussels, Belgium \\ Fred R. H. Zijlstra \\ Department of Work \& Social Psychology, University of Maastricht, \\ Maastricht, The Netherlands
}

\begin{abstract}
European research in Work and Organizational Psychology traditionally has a phenomenological orientation, favours comprehensive models, and stresses the role of individuals and situational factors in the work process. This means that individual characteristics of employees and the notion of cognitive regulation within situations have a prominent place. In this study, we used a framework that incorporates both these aspects as determinants of work behaviour (Roe \& Zijlstra, 1991) and applied this in research on psychological climate. Based on survey data from 406 hospital employees, we tested a model that specified organizational citizenship behaviour as a mediator of relationships between individual factors (psychological climate and self-efficacy) and work outcomes (quality of performance and emotional exhaustion). The results demonstrated support for our hypothesized model of how work behaviour mediates the relationship between these antecedents and outcomes. Practical implications and future research directions are discussed.
\end{abstract}

The research on climate in the IO literature seems to have taken a different course recently. In the past decade, a tendency seems to have emerged to focus on what Schneider (2000) has called the "climate for something". This "something" refers to core elements of the organizational mission and could be either "service", "safety", "innovation", or other organizational outcomes. Carr, Schmidt, Ford, and DeShon (2003) referred to this as a distinction between specific and molar models of climate. Molar models

Correspondence should be addressed to Dr Alessia D'Amato, Center for Creative Leadership, Avenue de Tervueren 270, B-1150 Brussels, Belgium.

E-mail: damatoa@leaders.ccl.org

Part of this research is based on the first author's PhD dissertation, which was supervised by Prof. Vicenzo Majer, University of Firenze, Italy. I am grateful to him and Prof. Rino Rumiati, University of Padova, Italy, for their support and comments.

(C) 2007 Psychology Press, an imprint of the Taylor \& Francis Group, an Informa business http://www.psypress.com/ejwop

DOI: $10.1080 / 13594320701307420$ 
incorporated more climate dimensions and focused on broader aspects of the work environment than the specific models. European research in Work and Organizational Psychology traditionally has a phenomenological orientation and favours comprehensive models. Furthermore, European models stress the role of individuals in the work process. This means that individual characteristics of employees and the notion of cognitive regulation have a prominent place in the European research tradition.

A number of researchers have proposed comprehensive models describing how situational variables and individual differences affect organizational outcomes, but few attempts have been made to test such general models, especially at the individual level of analysis (Ostroff, 1993). However, Carr et al. (2003) conducted a meta-analytic study and found indications for a relationship between a molar construct of climate and individual level outcomes. The aim of this article is to take up this challenge in an empirical study, and we will also argue that incorporating the element of individual differences and the regulative aspect of work behaviour will improve our understanding of the psychological processes underlying the relationship between climate and its outcomes.

So far, little attention has been paid to testing comprehensive models of the joint psychological effect of individual- and organizational-based variables on the results for both the person and his/her working environment. Therefore, we will test a model, based upon a heuristic framework (Ten Horn \& Roe, 1984; Zijlstra \& Roe, 1988), in which the concept of work behaviour plays a prominent role as a central regulative mechanism. Furthermore, this model incorporates concepts from the individual domain as well as the organizational domain, both as determinants (i.e., resources) of work behaviour and as results of work behaviour. This model fits well in the European tradition (Kuhl, 1992; Roe \& Zijlstra, 1991). This study examined the influence of personal and environmental (organizational) factors, and their interactions, on individual's behaviour and its outcomes.

\section{THEORETICAL BACKGROUND AND RESEARCH MODEL}

General models seem to be out of fashion in research on psychological and organizational climate. Currently there is a tendency to look at models that focus on specific elements of the organizational mission (cf. Burke, Borucki, \& Kaufman, 2002; Klein, Conn, \& Sorra, 2001; Schneider, Salvaggio, \& Subirats, 2002; Schneider, White, \& Paul, 1998; Zohar, 1980). Few attempts have been made to test comprehensive models such as the one proposed by James and Jones (1974), in particular at the individual level. According to Ostroff (1993), few studies have actually tried to look at the interaction between variables in the individual domain and variables in the 
organizational domain. And those studies that did make an effort generally failed to find statistical significant interactions. This is mainly due to the fact that those studies employed measures that were not in the same domain or measures that were not commensurate (Ostroff, 1993).

The European tradition is more phenomenologically oriented than the US and, from that perspective, favours holistic and general models. A typical example of such a theory is Hacker's "Handlungstheory" (Action Regulation Theory; Hacker, 1978, 1986, 2003; Frese \& Zapf, 1994). Hacker's theory provides an integrated framework for work behaviour; it describes how contextual variables and personal characteristics act as determinants for work behaviour. This theory has never been associated with organizational climate, but it can be argued that there are many overlaps and conceptual relations between Hacker's theory and general climate models (cf. Campbell, Dunette, Lawler, \& Weick, 1970; Hacker, 1964). A central element of Action Regulation theory is the focus on work behaviour. Work behaviour is conceived as predominantly goal-directed behaviour that is initiated by internal goals that are set by the individual. But these goals are the result of an interpretation and personal redefinition of the task instructions. This means that, as in theories on climate, the workers' appraisal of the task and the task environment will form the basis upon which they will act. We have chosen the general framework of this theory as a starting point for our study. Hacker's model has been presented in a generic scheme by Ten Horn and Roe (1984) and Zijlstra and Roe (1988), as presented in Figure 1.

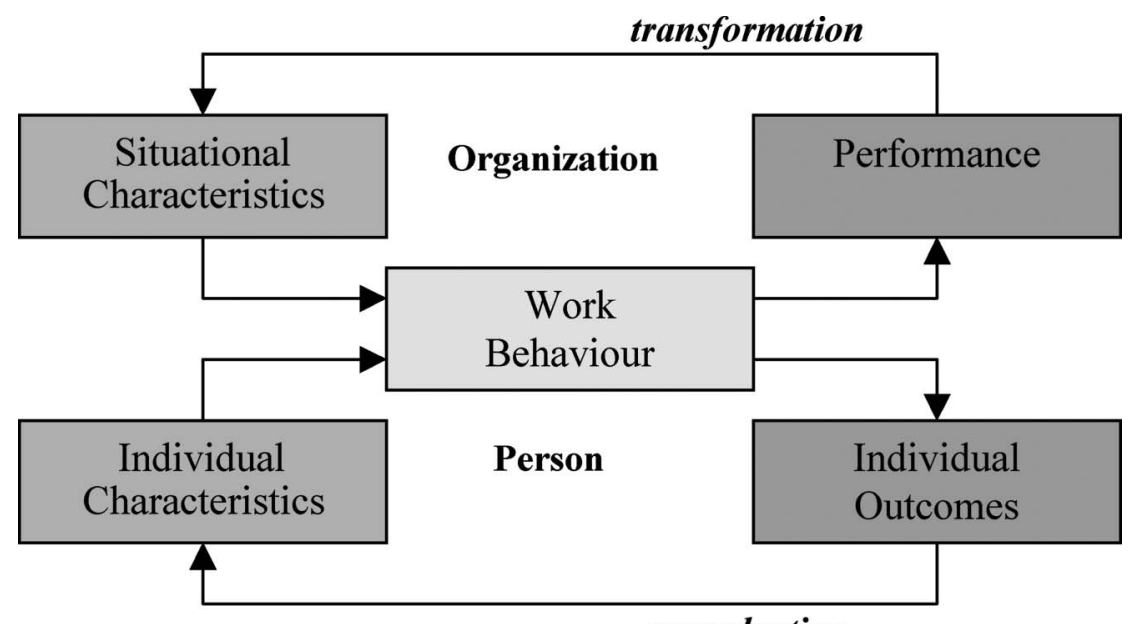

reproduction

Figure 1. The X-model, a schematic presentation (Roe \& Zijlstra, 1991). 
This is a schematic framework indicating that work behaviour is the central element in this model, and that work behaviour is determined by a person's appraisal of his/her work environment and their own skills and abilities. People do not respond to the work environment directly, but must first perceive and interpret their environment. Work behaviour mediates the relationship between contextual and individual aspects and the consequences of that behaviour.

The model in its present form is a generic model, but the level of aggregation can be chosen by specifying variables at the appropriate level. In this study, we will focus on the individual level rather than the organizational level. Thus, the context is represented by the job incumbent's perceptions of his/her work environment; this is usually referred to as psychological climate. The psychological climate can be distinguished from the organizational climate since the psychological climate is based on an individual's appraisal of the work situation, whereas the organizational climate is the shared appraisal of people in a group or team of the work setting of organizational policies, practices, and procedures that are recognized, supported, and rewarded in the organization (Schneider \& Reichers, 1983; Zohar \& Luria, 2004).

In the literature on Person-Environment Fit (PE Fit), the interaction between personal characteristics and environment is most often used to explain level of performance and job satisfaction. One way to look at PE Fit is to think of the congruence between the climate in the organization and personal characteristics. In an organization, not all individuals automatically give the same importance to all the rules and procedures, so there are likely to be differences in interpretation. Additionally, these rules and procedures will not affect all individuals' behaviour in the same way. For example, when an individual has a rather low level of self-confidence, or is less experienced, (s)he is much more likely to follow the rules strictly than employees with higher levels of self-efficacy or experience. Thus, work-related individual characteristics might lead to differences in work behaviour, in particular when workers have some discretion with respect to how to use their skills and knowledge, and thus can also cause differences in terms of outcomes. Personality influences people's behaviour at work, and thus the outcomes for clients.

Work behaviour refers to a wide array of behaviours that people display on the job. It is obvious that there is not one single parameter that can describe all aspects of work behaviour. From a conceptual point of view, work behaviour can be regarded as a direct expression of a person's interpretation and appraisal of the task (cf. Gollwitzer, 1993; Hacker, 1986; Hackman \& Oldham, 1975). For instance, it makes clear what activities people think that belong to their tasks, and it refers to how people work, i.e., their working style, methods, strategies, etc. Having some level of influence 
or control over the work is of course a prerequisite. Individual differences (with respect to knowledge, experience, self-efficacy, etc.), together with individual perceptions and appraisals of work environment, are likely to influence work behaviour. A worker's self-efficacy is an important determinant of work behaviour, because self-efficacy beliefs engender engagement in the work task, and stimulate people to do their best to perform at a high level, which is reflected in their work behaviour.

In the social-cognition literature, attitudes are conceptualized as learned predispositions to respond in a consistently favourable or unfavourable manner with respect to a given object or situation (Fishbein \& Ajzen, 1975). "Self-efficacy" is a set of preferences, values, and beliefs about oneself in relation to their environment (Bandura, 1977; Cooke \& Rousseau, 1983). Self-efficacy beliefs have been described as cognitive structures about people's appraisal of their capacity to master specific domains of actions, for example, the capacity to deal successfully with opportunities and challenges that are associated with the work role (Caprara et al., 2003). Judge and Bono (2001) showed that self-efficacy made a significant and substantial contribution to performance. A person's level of self-efficacy will influence the appraisal of the situation, the rules, and procedures that are applicable, and therefore will affect the decisions the person will make at work. Selfefficacy, together with the appraisal of the environment, determines how an employee will behave in the work situation. Therefore in our scheme the person will be represented by the variable "self-efficacy".

The degree to which people can commit to the group or organization to which they belong is also an important predictor for behaviour. When people can identify themselves with, and commit to the group, they are more inclined to accept the norms and values of that group, and are more likely to comply with the rules of the group (Salancik \& Pfeffer, 1977). Also, the more people agree with the objectives and rules of the organization and believe that these are congruent with their potential, the more they will comply with those rules and procedures, and act accordingly. This means that they will choose those behavioural options that are in line with the goals of the organization. For this reason, the concept of Organizational Citizenship Behaviour (OCB) was introduced (Koys, 2001; Organ, 1988). This concept refers to what extent people comply with what the organization expects them to do (and more). This concept can be regarded as a proxy for work behaviour in a service-oriented organization. Of course, this assumes that employees have some level of autonomy in their job to make choices between various behavioural alternatives.

OCB also refers to the extent to which people are willing to mobilize their resources or capacities to achieve the goals associated with the task. This illustrates that the appraisal of the task has a motivational implication and that, apart from the overt behaviours, there are also covert aspects of 
behaviour: the cognitive, energetic, and affective processes that accompany and regulate that behaviour. A person's commitment to the job is an example of such an affective aspect. Commitment represents the individual's belief in and acceptance of organizational goals and values. The stronger the commitment, the higher the desire to maintain membership of the organization (Mowday, Porter, \& Steers, 1982). However, in our model, individual work behaviour is represented by an aspect of overt behaviour (OCB).

Work behaviour will result in various outcomes such as the individual's performance, with performance being a direct result of the individual's activities at work. However, generally there are also other outcomes of being active, such as (psychological) fatigue, and so on. These are primarily relevant for the individual and may affect his/her well-being. In essence, this means that work behaviour mediates the relationship between environmental aspects (i.e., the task) and personal characteristics on one hand and the (organizational) outcomes on the other. In the organizational domain, the outcomes will be represented by individuals' assessment of their own performance; in the individual domain, outcomes are represented by individuals' assessment of their wellbeing. In this way, all variables specified in the model will be of the same aggregation level and referring to the same entity, thus meeting the requirement of being commensurate.

Psychological well-being is a phenomenological experience that involves an emotional component and can be seen as a global evaluation of the personal state (Wright \& Cropanzano, 2000). Well-being appears to be largely dependent on work-related factors, and to assess the impact of work on well-being, researchers mostly look at the negative impact of work on well-being, or rather the lack of well-being. A feeling of burnout is frequently used as an indicator of reduced well-being, and is often accompanied by feelings of depression, loss of self-esteem, and may also have physical components such as hypertension, and behavioural aspects like alcoholism and drug consumption. All these aspects have a detrimental effect on work outcomes (Quick, Quick, Nelson, \& Hurrell, 1997). Thus, it is likely that well-being and individual performance are related. Both these parameters refer to "outcomes" of behaviour; performance relates to the organization and burnout relates to the individual. And since we are referring to the individual's assessment of own performance, we believe both parameters can be considered to represent the commensurate results of work behaviour.

Furthermore, in line with the European tradition, it is assumed that people change and develop while they are interacting with their environment (Baltes, Staudinger, \& Lindenberger, 1999; Leontjew, 1978; Zijlstra, 1993). They will gain more experience, they will develop their skills, and thus enhance their qualifications. In this respect, the outcomes of work 
behaviour will have an effect on people's level of qualifications and their consciousness of this. When employees have done a good job, they are likely to feel good, and this may enhance their feelings of self-efficacy. In fact, people are "reproducing" their own qualifications because they learn from doing. One could call this the "reproduction" or "developmental" loop. This "learning hypothesis" is also included in the "extended" Job Demand Control Model (JDCM; Karasek \& Theorell, 1990). The extended JDCM predicts that strain will inhibit learning, while learning will prevent the development of strain.

Similarly, one could imagine that there is also a "developmental" loop as far as the organization is concerned: working can be seen as a "transformation" process. This transformation applies to both the "objects" of work, but also to the environment itself. One could assume that the organization changes over time. So, the performance does not only contribute to the organization achieving its goal or mission, it also helps to further develop the organizational climate. However, these elements are beyond the scope of this article as they can only be tested in a longitudinal study.

Therefore, our final study model is a specification of the heuristic framework as presented in Figure 1. The specific model is presented in Figure 2. This model has some similarities with the model presented by Carr et al. (2003), which is also based on the assumption that the impact of aspects of climate on the outcomes of interest (withdrawal, psychological well-being, performance) occurs through the impact on the cognitive and affective states of the employee. However, our model uses a wider construct (work behaviour), which is here operationalized as OCB. Compared to Carr et al.'s model, this means that in our model, OCB replaces "job satisfaction", which is usually seen as an "outcome" of behaviour and closely associated with withdrawal and turnover (Hackman \& Oldham, 1976). The research model specified in Figure 2 illustrates how appraisals of contextual and individual aspects flow together and amalgamate in behaviour and eventually result in tangible results. A stimulating psychological climate is a good resource for effective work behaviour that will have a positive impact on the outcomes-higher quality of performance and level of well-being.

Models on organizational climate usually focus on the relationship between climate and outcomes at an aggregate level-team or organization (Burke, Borucki, \& Hurley, 1992; Chan, 1998; Schneider et al., 1998). Also, it is implicitly assumed that climate has a uniform effect on all individuals, because individuals' characteristics are usually unnoticed. The present research aimed to examine the role of organizational and individual resources in predicting results for the person and the organization in a framework that posits work behaviour as the central construct. 


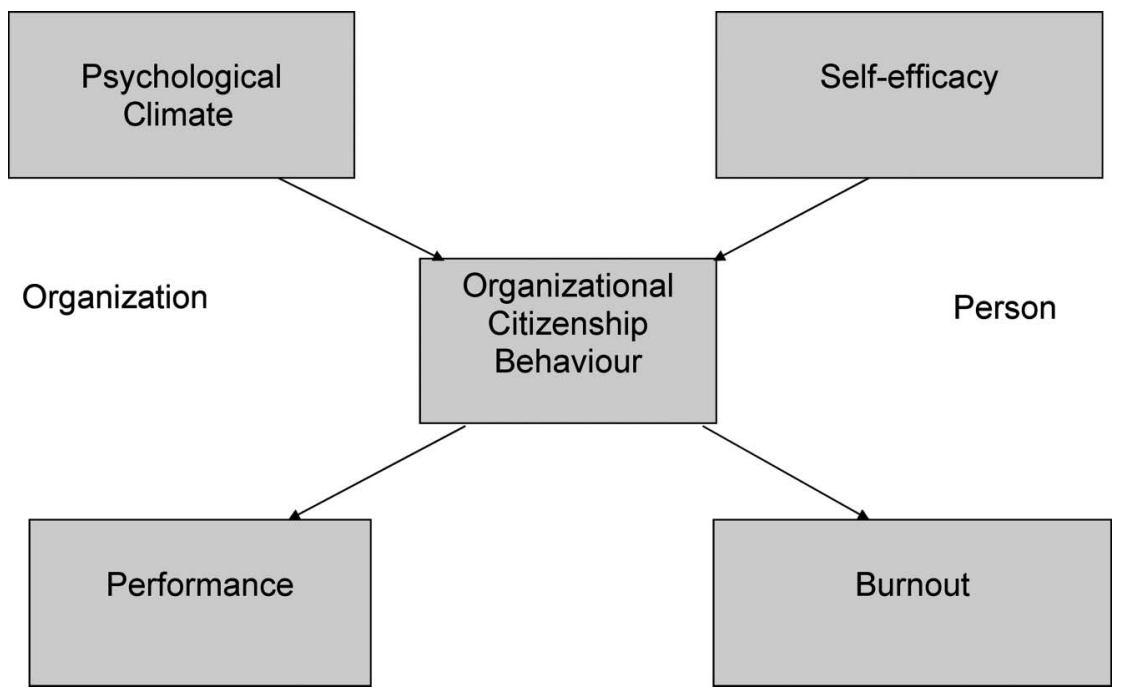

Figure 2. The Research model.

As indicated by Ostroff (1993), a prerequisite for finding significant results is that the measures that are used are commensurate (meaning in the same domain) and at the same level of aggregation. All the variables we have selected are related to the individual, and meet the requirement of commensuration.

\section{METHOD}

\section{Procedure and sampling}

The data we used were archival and collected as part of a consultancy project. The data were collected by surveying staff from a major hospital in the North of Italy. In many countries, the healthcare system has recently been through major changes. An important and common feature of these changes is that healthcare has been privatized, with a shift in the organizational vision, and as the first consequence, it is recognized that hospitals need to be more service oriented. This requires a different orientation from the whole organization, and lies foremost with hospital staff who have direct contact with patients. In this study, we focused on the psychological climate in the organization after the hospital had made the required changes towards privatization. In this hospital, the formal period of transition had been completed approximately $5-7$ years prior to this study. This means that we can safely assume that accompanying policies and procedures have settled in 
quite well, and that people have a common understanding of these policies and procedures, or in other words, a climate has developed (James \& James, 1989).

In consultation with the Human Resources department, six hospital wards that were considered to be representative of the whole organization were selected to participate in the study. The management of the ward was informed about the general purpose of the study. Participation in the study was voluntary, but the management encouraged and facilitated participation by allowing staff to participate during work time (i.e., attend meetings and fill in the survey). All responses were anonymous and confidential. Of the 512 employees invited, 408 returned the survey and 406 questionnaires appeared valid for analysis (a response rate of 79\%). Participants provided background information on gender, education, professional role, working hours, and shift/not shift.

All the professional categories, such as physicians (20\%), nurses and head nurses (35\%), nurse's aides and technical personnel (31\%), receptionists and administration (14\%), were represented in this sample. A small majority was female $(57 \%)$, most of them worked full time $(89 \%)$, while $69 \%$ worked in shifts, and $41.6 \%$ of the sample had been working in the organization for at least 15 years.

In terms of education, $31 \%$ had completed a junior secondary vocational programme, $46 \%$ had a high school or senior secondary vocational education, $9 \%$ had a higher vocational or college education, and $14 \%$ had a Masters or a Doctoral degree.

\section{Instruments}

The central constructs measured through the survey were: psychological climate, general self-efficacy, OCB, performance quality, and burnout.

Psychological climate. The M_DOQ10 (D'Amato \& Majer, 2005b; Majer \& D'Amato, 2001) was used to measure psychological climate. This instrument has been specifically developed for climate analysis and has been validated in the Italian context. As part of this project, a series of 10 focus groups and 30 exploratory interviews with staff, representing a range of occupations and hierarchical levels within the hospital, were conducted. Although a content analysis of the interview data is not within the scope of the current article, the results confirmed that all the major climate dimensions were included in the survey, in particular when also "climate for service" would be added to the scales of the M_DOQ10 (cf. D'Amato \& Majer, 2005a).

The M_DOQ10 consists of 10 scales: Communication (12 items; example item: "In my organization everybody is adequately informed about the 
objectives and outcomes"; Cronbach's alpha $=.82$ ); Autonomy (6 items; example: "In my job I have a certain amount of autonomy"; Cronbach's alpha $=.81$ ); Team Cohesion (11 items; example: "In my team people usually agree with each other"; Cronbach's alpha =.87); Job Description (5 items; example: "The tasks that are part of my role are clearly defined"; Cronbach's alpha $=.71$ ); Job Involvement (5 items; example: "My job is thrilling/ exciting"; Cronbach's alpha =.71); Dynamism/Development (5 items; example: "In my organization the decisions that are taken are implemented quickly"; Cronbach's alpha =.62); Reward Orientation (5 items; example: "Financial incentives are adequate when rewarding commitment and skills"; Cronbach's alpha $=.62)$; Supervision ( 8 items, example: "My supervisor is sensitive to my training needs"; Cronbach's alpha $=.80$ ); Innovativeness (5 items, example: "In my organization people are encouraged to find new ways around old problems"; Cronbach's alpha $=.78$ ); and Corporate Responsibility (8 items, example: "My organization makes an effort to adapt to social and political changes"; Cronbach's alpha $=.68)$. An eleventh factor has been added for the purpose of this study: Service Climate (9 items, example: "How would you rate the knowledge and skills of your team in delivering superior service quality?" Cronbach's alpha $=.88$ ). This factor measures the degree to which the organization is oriented towards delivering quality service to clients (Heskett, Sasser, \& Schlesinger, 1997; Schneider et al., 2002). This is an important aspect of service organizations (D'Amato \& Majer, 2005a, 2005b; Schneider et al., 1998).

Eleven different facets of climate have been measured. Burke et al. (1992), based on a Confirmatory Factor Analysis, have introduced the Multiple Stakeholder Perspective, in which they suggest that the dimensions of climate can be related to various stakeholders in the organization. Although there were slight differences in focus, Schneider et al. (1998) have referred to these as the "foundation" issues of the organization, and Zohar (2004) called them the "organizational priorities". Using this logic and procedure, and adopting the Schneider et al. terminology, we could demonstrate that the 11 factors of climate collapsed into three latent structures or "foundation issues".

The first foundation issue refers to the organizational policies (Innovativeness, Development, Rewards, Corporate Responsibility, Communication, and Service Orientation), the second to the job procedures (Autonomy, Job Description, Job Involvement), and the third issue refers to the (formal and informal) managerial practices (Team, Supervision) (cf. D'Amato, Rumiati, Majer, \& Crescentini, 2005). Cronbach's alphas were $.83, .70$, and .76 respectively.

These three meta-dimensions, or foundation issues, represent the organizational resources as appraised by the employee (i.e., the psychological 
climate). From a practical point, it is important that the number of climate dimensions is reduced, and from a theoretical perspective, this approach is relevant because it illustrates what the foundation issues of the organization are (Schneider et al., 1998).

General self-efficacy (GSE). GSE was assessed by a 10-item scale developed and validated by Schwarzer (1993) (example: "I always manage to solve difficult problems if I try hard enough"). The response categories are (1) "not at all true", (2) "barely true", (3) "moderately true", and (4) "exactly true". This global measure refers to one's general sense of competence and effectiveness (Cronbach's alpha =.84). All the items in the scale are job relevant but they capture individual self-appraisals. The instructions were referring to the work environment. In order to strengthen the measurement model of Structural Equation Models, it is suggested to have at least two indicators for each construct domain (Landis, Beal, \& Tesluk, 2000). For that reason, two separate factors have been composed out of the items of the GSE, through content analysis by two independent judges (Landis et al., 2000). Cronbach's alphas were .74 and .80 , respectively.

Organizational Citizenship Behaviour (OCB). OCB was measured with a five-item scale as developed by Koys (2001). Each item is a 5-point scale. Items were: (a) "The employees work to exceed the customer's expectations" (Conscientiousness); (b) "I can count on my co-workers when I need help" (Altruism); (c) "The whole team feels responsible for our success" (Civic Virtue); (d) "The people I work with have a 'can do' attitude" (Sportsmanship); and (e) "The people here treat each other with respect" (Courtesy) (Cronbach's alpha $=.73$ ).

The same procedure as with the GSE (splitting up the items) was followed for the $\mathrm{OCB}$ in order to construct two indicators for OCB (cf. Landis et al., 2000).

Performance quality. The single item technique (Nagy, 2002) was used to assess two aspects of work performance. Respondents' assessment of (a) the quality of their own performance, and (b) the quality of the team performance was obtained. Each aspect was rated on a 7-point Likert scale. As could be expected, the two aspects correlated quite highly (.83). Selfratings of performance are usually somewhat distorted in the sense that people tend to overestimate their own performance and/or the team they belong to (Freud, Colgrove, Burke, \& McLeod, 2005; Vest, Scott, \& Markham, 1994); however, of interest here is whether there is congruence between the assessments of the various levels. 
Burnout. Burnout was assessed with the Italian version of the Maslach Burnout Inventory (Sirigatti \& Stefanile, 1993). All three dimensions of the burnout construct (Emotional Exhaustion, Depersonalization, and Personal Achievement) were measured, but Personal Achievement (PA) has been excluded from the analysis (and models) because previous research in the context of service organizations suggested that PA is primarily a measure for self-assessed performance rather than well-being or mental health (D'Amato, Majer, \& Crescentini, 2005). Cronbach's alphas were .87 and .78 for Emotional Exhaustion and Depersonalization respectively.

\section{Data analysis}

SPSS version 11 (SPSS, 2001) has been used for assessing the psychometric properties of the measures, the descriptive statistics, and correlations.

In order to test a mediation model, it is advisable to use Structural Equation Modelling (SEM) rather than a series of linear regressions (Baron \& Kenny, 1986), because an SEM model allows the simultaneous assessment of the fit of measurement models and structural models (Landis et al., 2000). This is another aspect in which this study can be seen as an extension of previous studies (Carr et al., 2003; Martin, Jones, \& Callan, 2005; Ostroff, 1993).

Structural Equation Modelling (with LISREL version 8.1; Joreskog \& Sorbom, 1993) using maximum likelihood procedure (Bentler, 1990; Hu \& Bentler, 1995, 1998) was applied. Normal distribution of scale values was checked. In order to evaluate the fit of the models, several criteria were examined: (a) the chi-square $\left(\chi^{2}\right)$ : A small $\chi^{2}$ indicates that the observed data are not significantly different from the proposed model; (b) the ratio of maximum likelihood chi square to the degrees of freedom $\left(\chi^{2} / d f\right.$; Bollen, 1989), various rules of thumb ranging from 2 to 5 have been suggested as cutoffs for $\chi^{2} / d f$ (Byrne, 1989); (c) the adjusted goodness-of-fit index (AGFI; Joreskog \& Sorbom, 1993); (d) the root-mean-square error of approximation (RMSEA; Steiger, 1990). The RMSEA quantifies the discrepancy between the data and a proposed model per degree of freedom. Values below 0.06 (Ullman, 2001) indicate a good fit, whereas values up to 0.08 represent reasonable errors of approximation (Roelofs, Verbraak, \& Keijsers, 2005). Less restrictive is the approach by Cudeck and Browne (1993), who accept models with an RMSEA value of 0.10 or lower. Also the criterion of a GFI $\geq .90$ (Bentler \& Bonnet, 1980) was used to evaluate the goodness of fit.

\section{RESULTS}

Table 1 presents the means, standard deviations, and zero order correlations for the variables that were measured. 


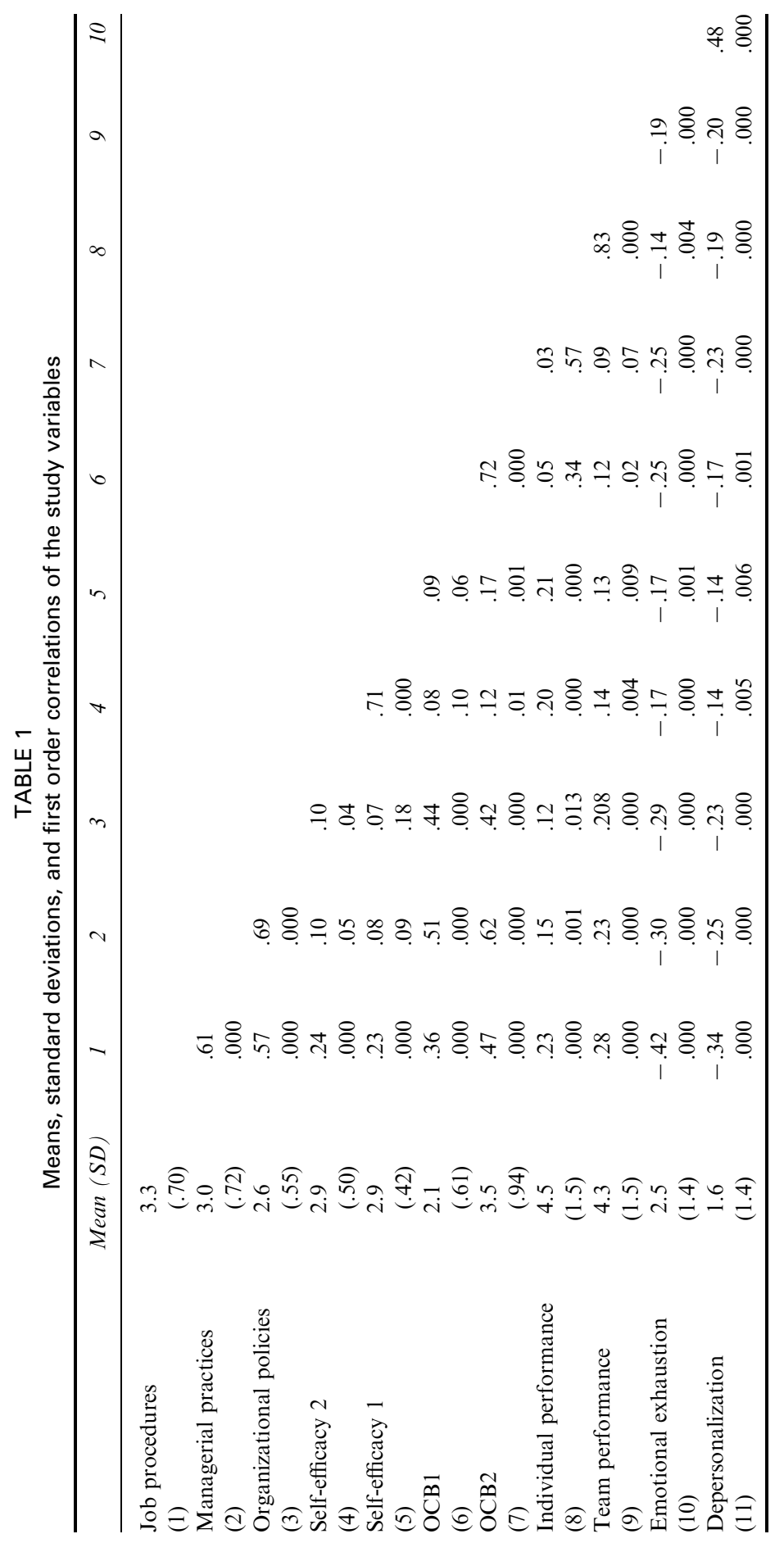


From Table 1, it is clear that the three foundation issues of the organization (organizational policies, managerial practices, and job procedures) are moderately positively correlated with each other. This is to be expected, as these three aspects refer to an underlying (positive) attitude towards the organization.

The aspects of self-efficacy are only substantially associated with the "employee" dimension of climate (job procedures), supporting the assumption that personality and appraisal of climate are related: a high level of self-efficacy influences the perception of rules and procedures and the way people use the autonomy they have in their job. The OCB indicators are also moderately related to the climate dimensions, in particular to the dimension "managerial practices". Again, this is in line with what one would expect. Furthermore, the OCB indicators do not correlate significantly with the self-efficacy indicators.

Both burnout dimensions are negatively related to all other variables, although correlations are weak. Emotional exhaustion is moderately negatively related to the climate aspects for employees.

The two performance indicators are highly correlated: Employees perceive no discrepancies between the quality of their own performance and the group performance, and apparently have a good understanding of the relevant procedures in this respect. This is a precondition for an adequate climate for service (James \& James, 1989; Schneider, 1975).

As a first step in the analyses, we used confirmatory factor analyses to verify the model with the three foundation issues. It appeared that the three factor model had a good fit with the data (Chi-square=74.4; $d f=38 ; \quad p=.000 ; \quad$ AGFI $=0.93 ; \quad$ RMSEA $=0.055)$. This demonstrates that the three foundation issues are indeed part of the latent construct "climate".

Subsequently, we tested our main hypothesis that the relationship between aspects of climate and outcomes is mediated by people's behaviour at work. Here Structural Equation Modelling was used.

The research model including OCB as a proxy for work behaviour fitted the data with a reasonable error of approximation (Chi-square=98.3; $d f=37 ; p \leq .0001$; RMSEA $=0.066$; Adjusted GFI $=0.94)$.

The SEM model is presented in Figure 3.

The test statistics indicate that the model fits the data well. The $\chi^{2} / d f$ ratio is slightly over $2\left(\chi^{2}=98.29 ; d f=37\right)$ and the RSMEA $=0.066$, indicating that the data fit the model with a reasonable error or approximation (Roelofs et al., 2005). The other "goodness of fit" indicators were as follows: $\mathrm{NFI}=0.95 ; \mathrm{NNFI}=0.95 ; \mathrm{CFI}=0.96 ; \mathrm{CN}=229.40 ; \mathrm{RMR}=0.044$; $\mathrm{SRMR}=0.053$; GFI $=0.95$, thus confirming the fit of the model with the data. The model clearly indicates that there is a strong positive association between climate and Organizational Citizenship Behaviour $(\gamma=.85)$, and 


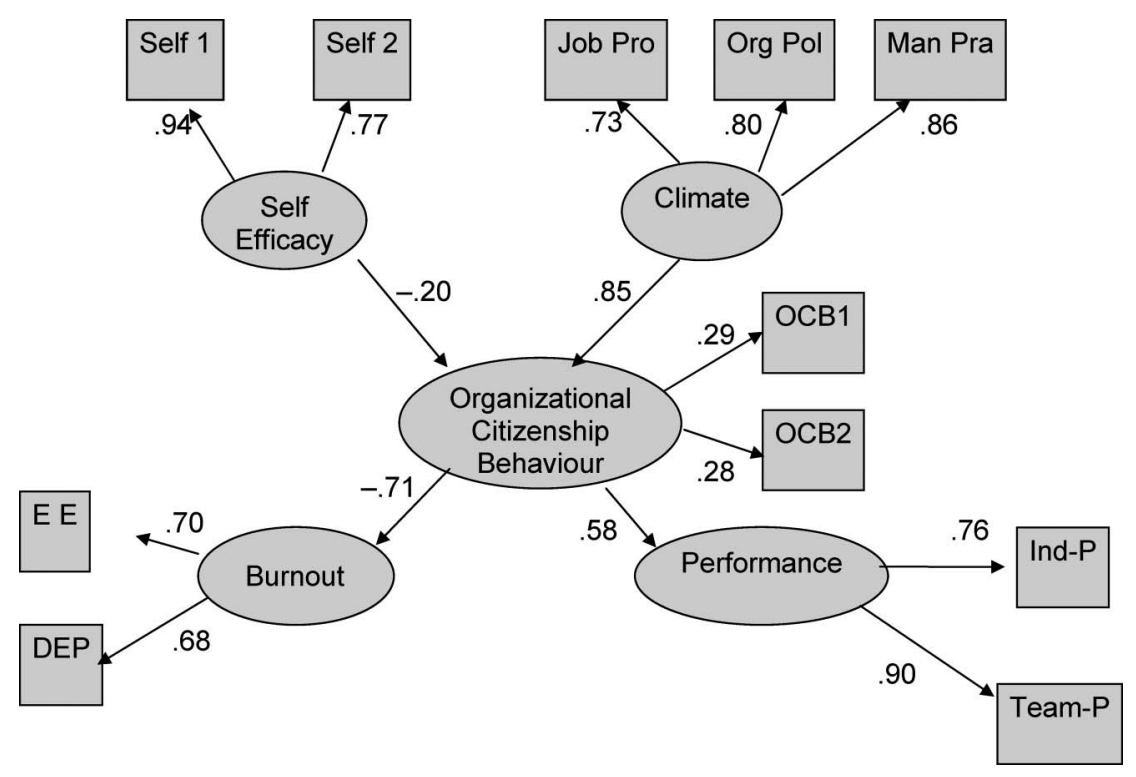

Figure 3. Model in which work behaviour mediates the relation between climate and outcomes. Job Pro $=$ Job Procedures, Org Pol $=$ Organizational Policies, Man Pra $=$ Managerial Practices, Climate $=$ Psychological Climate, Self $1=$ Self Efficacy (Factor 1), Self $2=$ Self Efficacy (Factor 2), OCB1 = Organizational Citizenship Behaviour $($ Factor 1), OCB2 $=$ Organizational Citizenship Behaviour (Factor 2), $\mathrm{EE}=$ Emotional Exhaustion, $\mathrm{DEP}=\mathrm{Depersonalization}$, Ind-P = Individual Performance, Team- $\mathrm{P}=$ Team Performance.

OCB is positively associated with performance indicators, indicating that OCB has a positive effect on performance. On the other hand, OCB is negatively associated with burnout, indicating that committed employees demonstrating Citizenship Behaviour usually do not suffer from feelings of burnout - or are less affected. Self-efficacy appears to be negatively related to OCB. This result supports our hypothesis that the way people behave at work mediates the relationship between climate and work outcomes.

\section{DISCUSSION}

The study findings reported here showed support for our hypothesis. OCB appears to mediate the relationship between the appraised work environment and self-efficacy on the one hand and performance and burnout on the other hand. This confirms the suggestions made by Carr et al. (2003) that the interpretation and evaluation of climate mediates the relationship with organizational outcomes. And, in fact, our study model suggested that 
individual differences interact with contextual factors to produce those outcomes. This model fitted the data adequately. There is consistent evidence that personality and performance are related (Barrick \& Mount, 1991; Judge \& Bono, 2001). Barrick, Mount, and Strauss (1993) observed how goal setting mediates the relation between Conscientiousness and Performance: Setting goals offers suggestions for conscientious workers to achieve those goals, which is directly related to performance. In this study, we found indications that self-efficacy and climate interact to influence OCB. A negative relation was found between self-efficacy and OCB. This can be explained by the fact that self-efficacy focuses strongly on individual competences, while OCB, as operationalized in this study, also takes the "team perspective" into account, and relates to being a "team player". This sometimes conflicts in the sense that people with high levels of self-efficacy may rely more on own competences than on others' competences. The net suppression (see Cohen \& Cohen, 1975) observed in the results pertaining to self-efficacy, psychological climate, and OCB is consistent with this point. In other words, in spite of its positive bivariate correlation with OCB, the function of self-efficacy (as measured in the study) seems to have been to suppress a portion of the variance in climate (unrelated to team functioning) that is irrelevant to OCB. The result being that the effect of climate on OCB (i.e., .85) is greater than any of the bivariate correlations between climate measures and OCB.

When we look at the model that has been tested, it is clear that the path between climate and OCB is stronger than the path between self-efficacy and OCB. This suggests that the contextual factors have a stronger influence on OCB than self-efficacy, and subsequently can be presumed to also have a stronger effect on outcomes of behaviour. Previous studies have already indicated that climate has an effect on the individual's level of well-being (e.g., Carr et al., 2003; Martin et al., 2005; Ostroff, 1993), but our study also suggests that contextual factors have a stronger effect than individual factors. That has important practical implications. It means, for instance, that (structural) changes in the organization may have a greater impact in terms of prevention of burnout than helping people to develop adequate coping styles.

One of the problems that have reportedly prevented many researchers from finding significant interactions between personality traits and work outcomes is related to the fact that it is difficult to find appropriate conceptualizations of both the environmental- and person-related variables (Ajzen \& Fishbein, 1977; Chatman, 1989). Ostroff (1993) referred to variables not being commensurate. We think that psychological climate and perceived self-efficacy can be considered to be commensurate measures insofar as they can both be characterized as "resources" (or determinants) of behaviour: climate as an environmental resource (Martin et al., 2005) and 
self-efficacy as an individual resource. This interpretation is supported by Halpin and Croft's (1962) reference to climate as the "personality" of an organization, because according to them, people tend to map personalitytype attributes onto the organization.

Few climate studies have included both climate and personal characteristics, or have directly examined the contribution of climate and personal factors to individual-level outcomes. Several shortcomings have been noticed in research using both personal and climate variables. For example, Ostroff (1993) suggested that the moderated regression approach is the most appropriate method to analyse interactions. In this approach, two independent variables are entered first into the regression equation, followed by the cross product of the two variables. However, we think that the structural equation modelling technique is a powerful technique, insofar as it allows measurement (model parameters) and path parameters to be measured simultaneously (Landis et al., 2000).

Our research model can be seen as an extension of the traditional research models on organizational climate, which assumes a direct relationship between aspects of climate and performance. From a theoretical perspective, the most extensive and comprehensive model is the most valuable since this is perceived as a more adequate description of real life. The essence of our model is that it makes clear that people's behaviour at work is determined by contextual variables (instructions, rules, task, etc.) and personal characteristics (skills, abilities, experience, etc.). The theoretical implication is that OCB is influenced by both the psychological climate and the employees' level of self-efficacy. Both elements jointly determine to what extent an employee will display a particular behaviour. Psychological climate refers to appraisals of the work context, and "self-efficacy" is used as an indicator for personal characteristics of the employee, while OCB was used as a "proxy" for work behaviour. The implication is that the choice for a particular behavioural option (i.e., work strategy) affects the level of performance (for example, the quality of the service delivered). Individual facets of the model (i.e., the relation of OCB with performance and burnout) have been tested before and were confirmed in this study. However, a comprehensive model like this has never been tested to its full extent with respect to climate.

The model is actually relatively simple, but has great didactic appeal because it clearly illustrates the relationships between the main conceptual elements that play a role in working life. Therefore, the presumed underlying processes can be clearly understood, and the model fits neatly into current theories on organizational behaviour. At the same time, this also constitutes the practical value of the model: For research and interventions, the model specifies what concepts have to be taken into account, and provides indications of the underlying psychological processes. 


\section{Study limitations}

This study evidently has some limitations. First of all, the cross-sectional design of the study does not allow causal inferences to be made. A longitudinal design would be required to test the causal implications of the model that was presented.

Second, the data are based on self-reports. This would usually invoke the criticism of inflated relations between variables due to, for instance, common-method variance. However, the focus of our study was on model fitting and theory testing and not statistical significance testing. Since our models were all based on the same variables, the amount of inflation would be the same for all models. As we are not interested in the absolute values of the associations between the variables, this problem does not affect this study.

\section{CONCLUSION}

In this study, we have demonstrated that aspects of work behaviour mediate the relationship between contextual aspects (rules, procedures, etc.), performance, and individual well-being. In climate research, the focus was traditionally on the relation between contextual aspects (i.e., climate) and performance outcomes. This study provided a theoretical extension to the approach of climate research by demonstrating that a holistic model that includes personal characteristics and work behaviour fits the data quite well, and thus provides an adequate description of life in an organization.

\section{REFERENCES}

Ajzen, I., \& Fishbein, M. (1977). Attitude-behavior relations: A theoretical analysis and review of empirical research. Psychological Bulletin, 84(5), 888-918.

Baltes, P. B., Staudinger, U. M., \& Lindenberger, U. (1999). Life-span developmental psychology. Annual Review of Psychology, 50, 471-507.

Bandura, A. (1977). Self-efficacy: Toward a unifying theory of behavioral change. Psychological Review, 84, 191-215.

Bandura, A. (1997). Self-efficacy: The exercise of control. New York: W. H. Freeman.

Baron, R. M., \& Kenny, D. A. (1986). The moderator-mediator variable distinction in social psychological research: Conceptual, strategic, and statistical considerations. Journal of Personality and Social Psychology, 51, 1173-1182.

Barrick, M. R., \& Mount, M. K. (1991). The big five personality dimensions and job performance: A meta-analysis. Personnel Psychology, 44, 1-26.

Barrick, M. R., Mount, M. K., \& Strauss, J. P. (1993). Conscientiousness and performance of sales representatives: Test of the mediating effects of goal setting. Journal of Applied Psychology, 5, 715-722.

Bentler, P. M. (1990). Comparative fit indexes in structural models. Psychological Bulletin, 107, $238-246$. 
Bentler, P. M., \& Bonnet, D. G. (1980). Significance tests and goodness of fit in the analysis of covariance structures. Psychological Bulletin, 88, 588-606.

Bollen, K. A. (1989). Structural equations with latent variables. New York: Wiley.

Burke, M. J., Borucki, C. C., \& Hurley, A. (1992). Reconceptualizing psychological climate in a retail service environment: A multiple stakeholder perspective. Journal of Applied Psychology, 77(5), 717-729.

Burke, M. J., Borucki, C. C., \& Kaufman, J. D. (2002). Contemporary perspectives on the study of psychological climate: A commentary. European Journal of Work and Organizational Psychology, 11(3), 325-340.

Byrne, B. M. (1989). A primer of Lisrel: Basic applications and programming for confirmatory factor analytic models. New York: Springer-Verlag.

Campbell, J. J., Dunette, M. D., Lawler, E. E., \& Weick, K. E. (1970). Managerial behavior, performance, and effectiveness. New York: McGraw-Hill.

Caprara, G. V., Barbaranelli, C., Borgogni, L., Petitta, L., \& Rubinacci, A. (2003). Teachers', school staff's and parents' efficacy beliefs as determinants of attitudes toward school. European Journal of Psychology of Education, 18(1), 15-31.

Carr, J. Z., Schmidt, A. M., Ford, J. K., \& DeShon, R. P. (2003). Climate perceptions matter: A meta-analytic path analysis relating molar climate, cognitive and affective states, and individual level work outcomes. Journal of Applied Psychology, 88(4), 605-619.

Chan, D. (1998). Functional relations among constructs in the same content domain at different levels of analysis: A typology of composition models. Journal of Applied Psychology, 83(2), $234-246$.

Chatman, J. (1989). Matching people and organizations: Selection and socialization in public accounting firms. Administrative Science Quarterly, 36, 459-484.

Cohen, J., \& Cohen, P. (1975). Applied multiple regression/correlation analysis for the behavioral sciences. New York: Wiley.

Cooke, R., \& Rousseau, D. M. (1983). Relationship of life events and personal orientations to symptoms of strain. Journal of Applied Psychology, 68, 446-458.

Cudeck, R., \& Browne, M. W. (1993). Constructing a covariance matrix that yields a specified minimizer and a specified minimum discrepancy function value. Psychometrika, 57(3), $357-369$.

D'Amato, A., \& Majer, V. (2005a). L'M_DOQ10, il questionario multi-dimensionale per la diagnosi del Clima Organizzativo. Firenze, Italy: Organizzazioni Speciali.

D'Amato, A., \& Majer, V. (2005b). Il Vantaggio del Clima (Ed. R. Cortina). Milan, Italy: Cortina.

D'Amato, A., Majer, V., \& Crescentini, A. (2005). Un modello empirico di funzionamento organizzativo: Clima, stress e ABQ dell'organizzazione. In A. D'Amato \& V. Majer (Eds.), Il Vantaggio del Clima (pp. 113-132). (Ed. R. Cortina). Milan, Italy: Cortina.

D'Amato, A., Rumiati, R., Majer, V., \& Crescentini, A. (2005). Un modello teorico di Clima Organizzativo tra analisi qualitativa e quantitativa. In A. D'Amato \& V. Majer (Eds.), Il Vantaggio del Clima (pp. 83-106). (Ed. R. Cortina). Milan, Italy: Cortina.

Fishbein, M., \& Ajzen, I. (1975). Belief, attitude, intention, and behavior: An introduction to theory and research. Reading, MA: Addison-Wesley.

Frese, M., \& Zapf, D., (1994). Action as the core of work psychology: A German approach. In H. C. Triandis, M. D. Dunette, \& J. M. Hough (Eds.), Handbook of industrial and organizational psychology (pp. 271-340). Paolo Alto, CA: Consulting Psychologists.

Freud, B., Colgrove, L., Burke, B. L., \& McLeod, R. (2005). Self-rated driving performance among elderly drivers referred for driving evaluation. Accident Analysis and Prevention, $37(4), 613-618$.

Gollwitzer, P. M. (1993). Goal achievement: The role of intentions. In M. Hewstone \& W. Stroebe (Eds.), European review of social psychology (Vol. 4, pp. 141-185). Chichester, UK: Wiley. 
Hacker, W. (1964). Die Arbeitsweise als Persönlichkeitsmerkmal. Probleme in Ergonomische Psychologie, 10, 59-70.

Hacker, W. (1978). Allgemeine Arbeits- und Ingenieurspsychologie, Psychische Struktur und Regulation von Arbeitstätigkeiten. Bern, Switzerland: Huber Verlag.

Hacker, W. (1986). Arbeitspsychologie. Bern, Switzerland: Huber Verlag.

Hacker, W. (2003). Action Regulation Theory: A practical tool for the design of modern work processes? European Journal of Work and Organizational Psychology, 12(2), 105-130.

Hackman, J. R., \& Oldham, G. R. (1975). Development of the Job Diagnostic Survey. Journal of Applied Psychology, 60, 159-170.

Hackman, J. R., \& Oldham, G. R. (1976). Motivation through the design of work: Test of a theory. Organizational Behaviour and Human Performance, 16, 250-279.

Halpin, A. W., \& Croft, D. B. (1962). The organizational climate of schools. Chicago: Midwest Administration Center, University of Chicago.

Heskett, J. L., Sasser, L. A., \& Schlesinger, L. A. (1997). The service profit chain: How heading companies link profit and growth to loyalty, satisfaction and value. New York: Free Press.

Hu, L., \& Bentler, P. M. (1995). Evaluating model fit. In R. H. Hoyle (Ed.), Structural equation modelling: Concepts, issues, and applications (pp. 76-99). Thousand Oaks, CA: Sage.

Hu, L., \& Bentler, P. M. (1998). Cutoff criteria for fit indexes in covaraince structure analysis: Conventional criteria versus new alternatives. Structural Equation Modelling, 6, 1-55.

James, L. A., \& James, L. R. (1989). Integrating work environment perceptions: Explorations into the measurement of meaning. Journal of Applied Psychology, 74(5), 739-751.

James, L. R., \& Jones, A. P. (1974). Organizational climate: A review of theory and research. Psychological Bulletin, 97, 251-273.

Joreskog, K. G., \& Sorbom, D. (1993). LISREL 8: User's reference guide [Computer software manual]. SSI International. Hillsdale, NJ: Lawrence Erlbaum Associates, Inc.

Judge, T. A., \& Bono, J. E. (2001). Relationship of core self-evaluation traits-self-esteem, generalized self-efficacy, locus of control, and emotional stability - with job satisfaction and job performance: A meta-analysis. Journal of Applied Psychology, 86, 80-92.

Karasek, R., \& Theorell, T. (1990). Healthy work: Stress, productivity, and the reconstruction of working life. New York: Basic Books.

Klein, K. J., Conn, A. B., \& Sorra, J. S. (2001). Implementing computerized technology: An organizational analysis. Journal of Applied Psychology, 86(5), 811-824.

Koys, D. J. (2001). The effects of employee satisfaction, organizational citizenship behaviour and turnover on organizational effectiveness: A unit-level, longitudinal study. Personnel Psychology, 54, $101-114$.

Kuhl, J. (1992). A theory of self-regulation: Action versus state orientation, discrimination, and some applications. Applied Psychology: An International Review, 41, 97-129.

Landis, R. S., Beal, D. J., \& Tesluk, P. E. (2000). A comparison of approaches to forming composite measures in structural equation models. Organizational Research Methods, 3, $186-207$.

Leontjew, A. N. (1978). Activity, consciousness, and personality. Englewood Cliffs, NJ: Prentice Hall.

Majer, V., \& D'Amato, A. (2001). L'M_DOQ, il questionario multidimensionale per la diagnosi del Clima Organizzativo. Padova, Italy: Unipress.

Martin, A. J., Jones, E. S., \& Callan, V. J. (2005). The role of psychological climate in facilitating employee adjustment during organizational change. European Journal of Work and Organizational Psychology, 14(3), 263-289.

Mowday, R. T., Porter, L. W., \& Steers, R. (1982). Organizational linkages: The psychology of commitment, absenteeism, and turnover. San Diego, CA: Academic Press.

Nagy, M. S. (2002). Using a single item approach to measure facet job satisfaction. Journal of Occupational and Organizational Psychology, 75(1), 77-86. 
Organ, D. W. (1988). Organizational citizenship behaviour. Lexington, MA: Lexington Books.

Ostroff, C. (1993). The effects of climate and personal influences on individual behavior and attitudes in organizations. Organizational Behavior and Human Decision Processes, 56, $56-90$.

Quick, J. C., Quick, J. D., Nelson, D. L., \& Hurrell, J. J. (1997). Preventive stress management in organizations. Washington, DC: American Psychological Association.

Roe, R. A., \& Zijlstra, F. R. H. (1991). Arbeidsanalyse ten behoeve van (her)ontwerp van func-ties: een handelingstheoretische invalshoek. In J. A. Algera (Ed.), Analyse van Arbeid vanuit Verschillende Perspectieven (pp. 179-243). Lisse, The Netherlands: Swets \& Zeitlinger.

Roelofs, J., Verbraak, M., \& Keijsers, G. P. J. (2005). Psychometric properties of a Dutch version of the Maslach Burnout Inventory General Survey (MBI-DV) in individuals with and without clinical burnout. Stress and Health, 21, 17-25.

Salancik, K., \& Pfeffer, J. (1977). An examination of need-satisfaction models of job attitudes. Administrative Science Quarterly, 23, 223-253.

Schneider, B. (1975). Organizational climate: An essay. Personnel Psychology, 28, 447-479.

Schneider, B. (2000). The psychological life of the organization. In N. M. Ashkanasy, C. P. Wilderon, \& M. F. Peterson (Eds.), Handbook of organizational culture and climate (pp. xxiii-xxx). Thousand Oaks, CA: Sage.

Schneider, B., \& Reichers, A. (1983). On the etiology of climates. Personnel Psychology, 36, $19-39$.

Schneider, B., Salvaggio, A. N., \& Subirats, M. (2002). Climate strength: A new direction for climate research. Journal of Applied Psychology, 87(2), 220-229.

Schneider, B., White, S., \& Paul, M. (1998). Linking service climate and customer perceptions of service quality: Test of a causal model. Journal of Applied Psychology, $83(2), 150-163$.

Schwarzer, R. (1993). Measurement of perceived self-efficacy: Psychometric scales for cross-cultural research. Berlin, Germany: Institut fur psychologie der Freie Universitat Berlin.

Sirigatti, S., \& Stefanile, C. (1993). MBI-Adattamento Italiano. Firenze, Italy: Organizzazioni Speciali.

Steiger, J. H. (1990). Structural model evaluation and modification: An interval estimation approach. Multivariate Behavioural Research, 25, 173-180.

Ten Horn, L. A., \& Roe, R. A. (1984). De Delftse Meetdoos voor kwaliteit van arbeid-orientatie voor gebruikers. Delft, The Netherlands: Delft University of Technology.

Ullman, J. B. (2001). Structural equation modeling. In B. G. Tabachnisk \& L. S. Fidell (Eds.), Using multivariate statistics (4th ed., pp. 653-771). Needham Heights, MA: Allyn \& Bacon.

Vest, M. J., Scott, K., \& Markham, S. E. (1994). Self-rated performance and pay satisfaction, merit increase satisfaction, and instrumentality beliefs in a merit pay environment. Journal of Business and Psychology, 9(2), 171-181.

Wright, T. A., \& Cropanzano, R. (2000). Psychological well-being and job satisfaction as predictors of job performance. Journal of Occupational Health Psychology, $5,84-94$.

Zijlstra, F. R. H. (1993). Efficiency in work behaviour: A design approach for modern tools [PhD thesis]. Delft, The Netherlands: Delft University of Technology.

Zijlstra, F. R. H., \& Roe, R. A. (1988). Ansätze zur Beanspruchungs- und Belastungsmessung in Verbinding mit neuen Technologien. In E. Frieling \& H. Klein (Eds.), Rechnerunterstützte Konstruktion, Bedingungen und Auswirkungen von CAD (Vol. 18-5, pp. 258-268). Bern, Switzerland: Huber Verlag.

Zohar, D. (1980). Safety climate in industrial organizations: Theoretical and applied implications. Journal of Applied Psychology, 65(1), 96-102. 


\section{D'AMATO AND ZIJLSTRA}

Zohar, D. (2004, April). Conceptualization and measurement of organizational climate: Safety climate as exemplar. SIOP Master Tutorial at the SIOP annual conference, Chicago.

Zohar, D., \& Luria, G. (2004). Climate as a social-cognitive construction of supervisory safety practices: Scripts as proxy of behavior patterns. Journal of Applied Psychology, 89, $322-333$.

First published online 27 September 2007 